\title{
YALE
}

\begin{tabular}{lll}
\hline Vol. XXIII JANUARY, 1914 & No. 3 \\
\hline
\end{tabular}

\section{PURCHASE FOR VALUE WITHOUT NOTICE}

In 1887, Dean Ames published in the Harvard Lave Revieve (1 H. L. R., pp. 1-16) an article under the above title. In it he put forth views novel and striking. It is the purpose of this paper briefly to state those views and then to examine their soundness.

Three positions advanced by him may be stated as follows: First: If $A$, holding the legal title to a physical res in trust for $B$, in violation of his trust, transfers the title to $C$, who pays value, and, when taking title and paying value, has no notice of the trust, he can, after learning of the breach of trust, keep the title freed from B's equity. Second: If $A$ owes $B \$ 1,000$ and $B$ declares himself a trustee of the debt for $C$, and then, in violation of his trust, assigns it to $\mathrm{D}$, who pays value, and, when taking the assignment and paying value, has no notice of the trust, $D$, after learning of the breach of trust, may reduce the legal chose in action to a legal chose in possession and retain it for his own benefit freed from C's equity. Third: If A holds the legal title to a physical res in trust for $\mathrm{B}$, and $\mathrm{B}$ declares himself a trustee of his equitable interest for $C$, and then, in violation of his trust, assigns it to $D$, who pays value and, when taking the assignment and paying value, has no notice of the trust, $D$, after learning of the breach of trust, may reduce the equitable chose in action to a legal chose in possession and retain it for his own benefit freed from C's equity.

As to the first position there is no controversy. There is controversy as to the second and third.

It will be noticed that, in the first position, the trust res assigned is a corporeal thing, while in the others, it is an incorporeal thing, being, in the second, a legal, and, in the third, an equitable chose in action. 
In his essay entitled, "The Disseizir of Chattels" ( $3 \mathrm{H}$. L. R., pp. 23-40, 313-328, 337-346), Dean Ames has shown, that while the title to a corporeal thing is transferable, the title to a chose in action, which is an incorporeal thing, is incapable of transfer. Consequently the purchaser of a corporeal trust res acquires title; the purchaser of an incorporeal trust res-a legal or equitable chose in action-whatever else he acquires, acquires no title.

We shall deal first with Dean Ames' views as to purchase for value without notice of a trust res which is a legal chose in action and then with his views as to purchase for value without notice of a trust res which is an equitable chose in action.

In discussing the nature of ownership Dean Ames says $(3 \mathrm{H}$. L. R., p. 315): "A derivative title is commonly acquired from an owner by purchase or descent. The title in such cases is said to pass by transfer. For all practical purposes this is a just expression. But if the transaction be closely scrutinized, the physical res is the only thing transferred. The seller's right of possession, being a relation betwen himself and the res, is purely personal to him, and cannot in the nature of things, be transferred to another. The purchaser may and does acquire a similar and coextensive right of possession, but not the same right that the seller had. What really takes place is this: the seller transfers the res and abandons or extinguishes his right of possession. The buyer's possession is thus unqualified by the existence of any right of possession in another, and he, like the occupant, and for the same reason, becomes absolute owner." See also $3 \mathrm{H}$. L. R., pp. 339-340:

The foregoing language is used of a physical or corporeal res. Obviously it has no application to an incorporeal res, to a chose in action.

"A right of action in one person," says Dean Ames ( $3 \mathrm{H}$. I. R., pp. 339-342), "implies a corresponding duty in another to perform an agreement or to make reparation for a tort. That is to say, a chose in action always presupposes a personal relation between two individuals. But a personal relation in the very nature of things cannot be assigned. Even a relation between a person and a physical thing in his possession, as already stated, cannot be transferred. The thing itself may be transferred, and, by consent of the parties to such transfer, the relation between the transferror and the thing may be destroyed and replaced by a new but similar relation between the transferee and the res.. But where one has a mere right against another, there is nothing that is capable of transfer. The duty of $B$ to $A$, whether arising ex 
contractu or ex delicto, may of course be extinguished and replaced by a new and co-extensive duty of $B$ to $C$. But this substitution of duties can be accomplished only in two ways; either by the consent of $\mathrm{B}$; or, without his consent, by an act of sovereignty. ***

"When the substitution of duties is by consent, the consent may be given either after the duty arises or contemporaneously with its creation. In the former case the substitution is known as a novation, unless the duty relates to land in the possession of a tenant, in which case it is called an attornment. A consent contemporaneous with the creation of the duty is given whenever an obligation is by its terms made to run in favor of the obligee and his assigns, as in the case of annuities, covenants, and warranties before mentioned, or to order or bearer, as in the case of bills and notes and other negotiable instruments. Here, too, on the occasion of each successive transfer there is a novation by virtue of the obligor's consent given in advance; the duty of the transferror is extinguished and a new duty is created in favor of the transferee.

"The practice of attornment prevailed from time immemorial but was confined to the transfer of reversions and remainders. Novation, although now a familiar doctrine, was, if we except the case of obligations running to the obligee and his assigns, altogether unknown before the days of assumpsit upon mutual promises. The field for the substitution of duties by consent was, therefore, extremely limited, and in the great majority of cases a creditor would have found it impossible to give another the benefit of his claim had not the ingenuity of our ancestors devised another expedient, namely, the letter of attorney. By such a letter, the owner of a claim appointed the intended transferee as his attorney, with power to enforce the claim in the appointor's name, but to retain whatever he might recover for his own benefit. In this way the practical advantage of a transfer was secured without any sacrifice of the principle of the inalienability of choses in action. ***

"By statute, in many jurisdictions, the assignee may even sue in his own name. But it is important to bear in mind that the assignee under the statute still proceeds in a certain sense as the representative of the assignor. The statute of itself works no novation. It introduces only a change of procedure. A release by the assignor of the debtor, ignorant of the assignment, extinguishes all liability of the debtor to anyone.

"So, if the assignor should wrongfully make a second assignment, and the second assignee should collect the debt, he would keep the money, and the first assignee would get nothing." (See also 1 H. L. R., pp. 6-7.) 
Dean Ames then adds that while formerly the power of attorney to enforce the claim for the attorney's own benefit had to be express, today it will be implied from circumstantial evidence. ( 3 H. L. R., p. 341, note 2.)

"The most striking difference," says Dean Ames $(1 \mathrm{H}$. L. R., pp. 9-10), "between property in a thing, and property in an obligation is in the mode of enjoyment: The owner of a house or a horse enjoys the fruits of ownership without the aid of any other person. The only way in which the owner of an obligation can realize its ownership is by compelling its performance by the obligor. Hence, in the one case, the owner is said to have a right in rem, and, in the other, a right in personam."

A. owing $B$ a debt of $\$ I, 000$ payable in.money, delivers to $B$ in payment that amount of money and $B$ then delivers the same to $C$. $A$ was under an obligation to $B$ to pay him $\$ 1,000$ in money and $\mathrm{B}$ had a corresponding right to compel $\mathrm{A}$ to pay him that amount of money. The payment to $B$ extinguished both A's obligation and B's right. The extinguished debt, which was a chose in action, was replaced by a chose in possession, that is, a corporeal thing, namely, $\$ 1,000$ of money. The title to this money, this corporeal thing, which was first in $A$, passed from $A$ to $B$ and then from $B$ to $C$, and $C$ can enjoy the fruits of ownership of the money without the aid of $A$ or $B$ or any other person.

$A$ owes $B$ a debt of $\$ 1,000$ payable in money and $B$ assigns the debt to $C$. Here $C$ does not, as in the last case, acquire from $B$ the title to $\$ 1,000$ of money, a corporeal thing, which he as owner can enjoy without the aid of any other person. Nor does he acquire from $B$ the legal title to the debt, as that is a chose in action, a personal relation between $A$ and $B$ and, therefore, incapable of transfer. If, then, $C$ acquires the legal title to nothing, what is it that he does acquire? According to Dean Ames he acquires power from $B$, as B's attorney and in B's name, to collect from $A$ \$1,000 of money, and, if necessary for such collection, to sue $A$ in a court of common law in B's name and then to retain the money collected for his own benefit. "Retain the money for his own benefit." What do these words signify? Of course, when $C, B$ 's attorney, collects $\$ 1,000$ of money from $A, C$ and not $B$ receives the money. $C$, therefore, not $B$, has possession. The title, however, does not follow the possession. The title to the money paid by $A$ to $C$, B's attorney, vests not in $C$, but in $B$, just as when $A$ pays the money to $B$ in person. When $A$ pays the money to $B$ the title and possession are united and both in $B$; 
when he pays it to $C, B$ 's attorney, the title and possession are separated, the title being in $B$, the possession in $C$. But if $C$, having in his possession money, the title to which is in $B$, is to "retain it for his own benefit," the title to the money must pass from $B$ to $C$. As $B$, after assigning the debt to $C$, is to do nothing further in person, $C$, as attorney for $B$ and in B's name, must pass the title from $B$ to himself. Thus it is that $C$ acquires the right to retain the money collected by him as A's attorney and in his possession as such attorney "for his own benefit" instead of accounting for it to his principal $B$, as he would otherwise have to do. It will be seen, therefore, that $C$ as assignee of $B$, that is, as attorney for $B$, acquires the power (1) to extinguish the debt or chose in action, (2) to receive from $A$ in lieu of the chose in action extinguished a chose in possession, and (3) to pass the title to such chose in possession from his principal, $B$, to himself, the attorney, for his own benefit. When $B$ collects the money and delivers it to $\mathrm{C}, \mathrm{C}$ acquires title to it. When $\mathrm{C}$, as B's attorney, collects the money and passes the title to it from $B$ to himself $C$ acquires title to it; C's title in either case, is acquired from $B$. The result in both cases is the same, though the methods by which it is reached vary.

Assume, now, that $B$, when he assigns the debt to $C$, holds it in trust for X, what are C's rights? If, says Dean Ames, when C receives the assignment and pays value, he has no notice of the trust, equity should permit him, even after learning of X's equity, to collect the money and retain it for his own benefit freed from X's equity. In other words, after the debt or chose in action has been reduced to a chose in possession, which is a corporeal thing, though $C$ knows that $B$ holds the legal title to that corporeal thing in trust for $\mathrm{X}$ and that $\mathrm{B}$ acting in person cannot confer on him (C) a title which he can hold freed from $X$ 's equity, still $\mathrm{B}$, acting by $\mathrm{C}$, his attorney, can do what acting in person he cannot do.

Suppose $B$, instead of assigning for value the debt to $C$, had agreed with $C$ for value to collect the debt and deliver the money collected to him, and that $\mathrm{C}$, when making the agreement and paying value, had no notice of $X$ 's equity, could $C$, after learning of the trust, be permitted to receive the money from $B$ and hold it freed from $X$ 's equity? Of course not. Change the illustration slightly. Suppose B had agreed that after he should collect the money, $\mathrm{C}$, as his attorney, should pass the title to the money from 
$B$ to $C$, could $C$, after learning of the trust, exercise the power of attorney and hold the title so acquired freed from X's equity? The question, we submit, answers itself.

The collection by C, as B's attorney, of the money from A, is in itself unobjectionable, even though made with knowledge of the trust. The objectionable thing is the retaining it for his own benefit; that is, the acquiring of title to the money from $B$ with full knowledge that he is acquiring title by a breach of B's trust.

$A$, holding the legal title to land in trust for $B$, borrows money from $C$, and, as security, delivers to $C$ the title deeds and also a power of attorney to execute a legal mortgage of the land to himself, $C$ then knowing nothing of the trust. 'Subsequently $C$ learns of the trust and executes to himself a legal mortgage. It was held in Taylor v. London and County Banking Company, L. R., 2 Ch. (1901), 231, that $C$ must hold subject to the trust. The decision, we submit, is sound.

Suppose, after $B$, the trustee of $X$, assigns the debt to $C, A$ pays the money to $B$ and $B$ delivers it to $C$, who receives it with knowledge of the trust. Can he retain it freed from X's equity?

As Dean Ames bases his contention on the decision in Dodds $v$. Hills, 2 H. \& M., 424 (1865), we must see what that decision involves. Shares of stock in a company were standing in Hill's name. He borrowed money of Smith and, as security, executed to Smith "a transfer of said shares" and handed it to him together with a certificate of the shares. In fact Hills was trustee of the shares for Mrs. Dodds, but Smith, when he received the "transfer" and certificate and paid value, had no notice of the trust. Hills having absconded and Smith, having learned of Mrs. Dodds' equitable interest, delivered the "transfer" and certificate to the company and was registered as owner of an equal number of shares. Mrs. Dodds then sued and prayed that the "transfer" be set aside or she be let in to redeem. She was let in to redeem on payment of Hills' debt to Smith.

Dean Ames ( 1 H. L. R., pp: 5-6) states this decision thus: "A trustee of shares in a company wrongfully pledged them, transferred the certificates and executed a power to the innocent lender to register himself as owner of the shares. The 'transfer' was registered after the lender was informed of the breach of trust. (Italics ours.) Wood V. C., refused to deprive the lender of his security." 
The context shows that Dean Ames in saying Hills "executed a power" to Smith meant a power of attorney. The report of Dodds $v$. Hills says nothing either of Hills having "executed a power" to Smith "to register himself as owner of the shares" or of the transfer having been registered. The V. C., it is true, says "Smith required Hills to give him by way' of indemnity, such a power over the shares as would enable him, Smith, whenever he pleased, to make himself legal owner. That Hills did by executing a transfer."

This, we take it, does not mean that Smith required Hills to execute to him a power of attorney to do anything. All that the V. C. means is that Smith required Hills to do that which was necessary to put Smith in a position to require the company to accept from him a surrender of Hills' shares, to issue to him in their place a like number of new shares and to register him as owner of such new shares, and that Hills did what was necessary by executing the so-called transfer. There is no suggestion that Hills made Smith, expressly or impliedly, his attorney to do anything or that it was necessary that Smith should do anything as attorney for Hills to have himself substituted as a stockholder in Hills' place.

When A holds shares of stock in a corporation he owns a chose in action. The chose in action is a personal relation between $\mathrm{A}$ and the corporation and, therefore, incapable of transfer. But the personal relation between $A$ and the corporation can be destroyed and replaced by a new but similar and co-extensive personal relation between $B$ and the corporation. Such a substitution is called a novation. It was a novation that was effected in Dodds v. Hills. Smith surrendered Hills' shares to the company and received new shares in lieu of those surrendered and extinguished. The personal relation between Hills and the company was destroyed and replaced by a new but similar and co-extensive personal relation betwen Smith and the company. Hills ceased to be a stockholder and Smith became a stockholder in his stead.

The decision in Dodds v. Hills cannot be understood without understanding what must be done to effect what is called a "transfer" of shares of stock in a company.

Suppose $A$ is the registered owner of one hundred shares of stock of a corporation, which we will call the Jones Company, for which he holds a certificate and that he wishes to "transfer" these shares to $B$. 
The Jones Company will probably have three books; one known as the "transfer" book, another as the stock certificate book, and a third as the stock ledger. In the "transfer" book will be printed blank "transfers" in this form: "For value received ......hereby assign and transfer unto..... shares in the capital stock of the Jones Company." The certificate book will contain printed blank certificates with margins for entering the time of issuing the certificate, the number of shares, the number of the certificate and to whom issued. The stock ledger will contain an account with each shareholder, in which he is credited with all shares "transferred" by others to him and debited with all shares "transferred" by him to others.

If the certificate of the Jones Company has the form usual today in this country, after declaring A entitled to one hundred shares of the capital stock of the Jones Company, it will state that they are transferable on the books of the company at its office by $A$ or attorney on the surrender of the certificate.

One method of "transfer" is this: A delivers to B his (A's) certificate. A and $B$ then go to the company's office and see the "transfer" clerk. A signs in the "transfer" book an assignment and "transfer" to B of all right, title and interest in one hundred shares of the capital stock of the Jones Company. B surrenders to the company the certificate held by him for cancellation. The "transfer" clerk takes from the certificate book a blank form of certificate and fills in B's name as entitled to one hundred shares of the capital stock of the company, has it signed by the proper officers and delivers it to $B$. He then debits $A$ in his account in the stock ledger with one hundred shares "transferred" by him to $B$ and opens an account with $B$ and credits him with the one hundred shares "transferred" to him by A.

Another method is this: A delivers the certificate to $B$ and also a formal instrument of assignment and "transfer" signed by A. This may be separate from the certificate, but is generally printed on its back. Despite this "transfer" A still goes to the company's office and signs an additional assignment and "transfer" in the company's "transfer" book.

A third and the most usual method is this. A delivers the certificate to $B$. He also signs and delivers to $B$ a formal instrument of assignment and "transfer" and power of attorney authorizing a person, whose name is generally left blank, to be subsequently filled in, to sign a "transfer" in the corporate "trans- 
fer" book. This enables the "transferee" to have himself registered as owner without A's presence. The blank power of attorney is generally filled in by the "transfer" clerk writing in his own name, who thereby becomes A's attorney to sign the requisite "transfer" in the company's "transfer" book. The "transfer" and power of attorney may of course be separate from the certificate or, as is usual, printed on the back of the certificate.

Much information on the method of effecting what is called the "transfer" of shares of stock in a company can be had by consulting the case of The New York and New Haven Railroad Company v. Schuyler et al., 34 N. Y., 30, pp. 36-38, and Cook on Stock and Stockholders (3d ed.) sec. 375.

The question naturally arises, why does $A$ either in person or by attorney sign an assignment and "transfer" in the "transfer" book of the company, after having already signed such an assignment and "transfer" and delivered it to $B$. If $B$ delivers to the company the certificate and "transfer", the company has ample authority to cancel the shares represented by the certificate and issue a like number of new shares in their place. The reason would seem to be one of convenience only, that the company may have its "transfers" bound together in book form, rather than detached from each other. The second "transfer" in the "transfer" book is superfluous and the company may dispense with its requirement. Indeed the writer is informed by the secretary of a New York company that it has no "transfer" book; that the person to whom a certificate is issued signs a receipt for it in the stock certificate book, and, when a person surrenders that certificate with a "transfer" endorsed on it bearing the same signature as the receipt, the company cancels the certificate and issues a new one to the person surrendering the old one.

In Dodds v. Hills Hills delivered to Smith a certificate and a so-called "transfer of said shares," and Smith delivered both to the company. Nothing is said of a corporate "transfer" book or of Hills or Smith or anyone else executing. any "transfer" other than the one executed by Hills to Smith and delivered by Smith to the company. The company, so far as appears, accepted this as sufficient and did what was necessary to substitute Smith as a registered shareholder in place of Hills.

What then becomes of Dean Ames' view of the decision in Dodds v. Hills? The question whether Smith had authority as Hills' attorney and in Hills' name to execute a "transfer" of Hills' 
shares to himself did not arise, as Hills himself had executed such a "transfer" and the company required no other evidence of Smith's right to be substituted in place of Hills as shareholder.

We wish not to misrepresent Dean Ames. The difficulty lies in his lack of clearness in the use of language. In stating the decision in Dodds $v$. Hills, he says, in language already quoted (1 H. L. R., p. 5), Hills "executed a power to" Smith "to register himself as owner of the shares". "The shares" were Hills' shares and of these Smith could not register himself as owner nor be registered as owner by the company. Hills' shares had to be extinguished and a like number of new-shares issued in their place and it was of these new shares only that Smith could be registered as owner. Moreover had Hills, as Dean Ames states, executed to Smith a power of attorney "to register himself as owner" it would have been ineffectual. For Smith could not register himself as owner; only the company could register him as owner. A similar want of clearness is seen in Dean Ames' further statement: "The transfer was registered after the lender was informed of the breach of trust." "A "transfer" is never registered. Perhaps Dean Ames means that Smith became a stockholder in lieu of Hills and was registered as such after he was informed of the breach of trust. If so, that was the fact. But he still leaves us in doubl as to just what he thinks Smith, as Hills' attorney, was empowered to do.

The careful reader will have noted that the word "transfer" is used in two meanings. In one sense it is applied to a formal instrument of "transfer" executed by the so-called "transferror," in person or by attorney, to the so-called "transferee" and contained at times in the corporate "transfer" book and at times not. In the other sense it seems to mean the completed transaction by which one person is substituted in place of another as stockholder in a corporation, which, of course, is not a "transfer", but a substitution or novation.

In note 1 to Milroy v. Lord, at p. 155 of his Cases on Trusts (2d ed.), Dean Ames says: "A delivery of the certificates, coupled with the execution of an express power of attorney to the donee to 'transfer' the shares on the company's books, makes him substantially dominus of the shares, since he needs no further assistance from the donor, and can compel registration by the company." "Nor is an express power of attorney indispensable. A delivery of the certificates as a gift carries by necessary implica- 
tion a power to transfer the shares on the company's books." This language coupled with the authorities cited in the note show that Dean Ames in speaking of a "power of attorney to 'transfer' the shares on the company's books" means a power of attorney to sign with the "transferor's" name a formal instrument of "transfer" such as is found in corporate "transfer" books, the form of which has been given above. If this be Dean Ames' meaning, then when $A$, a stockholder in a corporation, delivers a certificate of shares of stock to $B$, with the intent that $B$ shall become a stockholder in his place, $B$, by necessary implication, becomes A's attorney, with power to sign A's name to a so-called instrument of "transfer" of the shares represented by the certificate from $A$ to $B$ and thus put himself in position to compel registration by the company as a stockholder

We can now compare the power of attorney of the so-callerl assignee of shares of stock with that of the so-called assignee of a debt. The assignee of shares has the right to sign the assignor's name to a formal instrument of assignment and "transfer", as it is called. Of course, as the assignor's interest as a stockholder in the corporation is a chose in action and, therefore, incapable of assignment and "transfer" by the stockholder, acting either in person or by attorney, the so-called assignment and "transfer" is not what it terms itself. It operates to assign and "transfer" nothing. It does not even operate to create a power of attorney in the assignee or transferee, for, ex hypothesi, it is the delivery of the certificate with the requisite intent that makes the assignee. the assignor's attorney. The assignee by signing the assignor's name to the formal instrument of assignment and "transfer" r.reates no new substantive right in himself. At most the formal instrument of assignment and "transfer" is mere evidence to the company of the assignee's right to be substituted as stockholder in place of the so-called assignor or "transferror".

The so-called assignee of shares in surrendering to the company the assigned shares for cancellation and extinguishment does not act as attorney or agent of the assignor; nor, in taking title in his own name to the new shares issued in lieu of the extinguished shares, is he acting as his attorney. When the assignor's shares are extinguished, the legal title to the shares issued in their stead does not first vest in the assignor and then pass from him to the assignee to be then retained by him for his own benefit. If, therefore, when the new shares are issued to the assignee he knows of 
the breach of trust committed by his assignor in making the socalled assignment to him, he does not acquire title to the shares by means of a new breach of trust by the assignor. "In Dodds $v$. Hills," says Dean Ames, "it will be noticed, that the lender was able to complete his title under the power without further assistance from the delinquent trustee. If the lender required the performance of some further act on the part of the trustee in order to complete his title, and if before such performance he received notice of the trust, the loss will fall upon him." (1 H. L. R., p. 6, note 1.)

When the assignee of a debt collects it, there is no substitution of a new debt for the debt collected and extinguished; there is no novation. The debt extinguished is replaced by a chose in possession. The debtor's obligation is performed and no obligation remains to be performed. That is not the case where there is a novation. No obligation has been performed. One obligation has replaced another, but still remains to be performed. The title to the chose in possession that takes the place of the debt, like the title to the debt extinguished, vests in the assignor, and must pass from the assignor to the assignee before he can retain it for his own benefit. After it vests in the assignor and before it passes from him to the assignee, the assignor holds the legal title in trust and it is a new breach of his trust to pass the title to the assignee; and if the assignee, when taking title, knows of the trust, he participates in the breach. The fact that the assignor in passing title to the assignee acts not in person but by attorney makes the act no less his act in point of law and, therefore, no less a breach of trust. Nor does the fact that the attorney by whom the assignor acts is the assignee himself make the act less a breach of trust. And as to the assignee, he is doubly at fault, for he acts for both assignor and assignee in committing the breach of trust.

Dean Ames admits that the English decisions are opposed to his view and that the courts of New York follow the English decisions, but says that a qualification is made in favor of an assignee whose assignor is himself an assignee under a written assignment procured by fraud. He then cites Moore v. Metropolitan Bank, 55 N. Y., 41 (1873), and adds: "The decision in Moore v. Metropolitan Bank is, therefore, repugnant to the English rule which the courts in New York profess to follow." 
The facts in that case were these: The plaintiff, Moore, owned a certificate of indebtedness of the State of New York for $\$ 10,000$ and delivered it to Miller with an endorsement signed by himself as follows: "For value received, I hereby transfer, assign, and set over to Isaac Miller the within described amount, say ten thousand dollars." Miller procured the assignment by fraud and paid plaintiff nothing. He then delivered the certificate to the defendant bank, as security for a loan, with a similar assignment from himself. The Court of Appeals refused to deprive the bank of its security but permitted plaintiff to redeem on payment of Miller's debt to the bank.

The assignment from plaintiff to Miller was a power of attorney and substitution ( $1 \mathrm{H}$. L. R., p. 8). Miller, therefore, had the right to substitute another in his own place as plaintiff's attorney to collect. The substituted attorney would be as much the attorney of plaintiff as was Miller. The assignment by Miller to the bank was a substitution of the bank in his own place as attorney for plaintiff to collect. A novation of powers of attorney, so to speak, was effected. For such substitution or novation the bank paid value in ignorance of Miller's fraud. The bank, therefore, took Miller's place as assignee from plaintiff and, having paid value in ignorance of Miller's fraud, it was in the same legal position as if it had taken its assignment immediately from the plaintiff and for value. If the bank, therefore, had collected $\$ 10,000$ in money of the State of New York, after learning of Miller's fraud, no reason appears why it should not retain the money for its own benefit to the extent of its loan to Miller. The title to the money collected before passing from plaintiff to the bank would not be held by plaintiff as trustee and, therefore, there would be no breach of trust in the acquisition by the bank of title from the plaintiff. If, however, plaintiff, when he assigned to Miller, had held the certificate in trust for $\mathrm{X}$ and then the bank had collected the money and passed the title to itself from the plaintiff, knowing plaintiff to be trustee for $X$, the bank should hold the title subject to X's equity. We fail to see wherein Moore v. Metropolitan Bank is repugnant to the English rule which the courts of New York profess to follow.

We now pass to consider Dean Ames' views in respect to equitable choses in action. He says the law of transfer is the same for corporeal things and equitable obligations. "Take for instance," he says, "the case of land. The owner may diminish 
his interest (1) by a transfer of the whole or an aliquot part of the land either permanently or for a time; (2) he may grant a rent charge issuing out of the land; or (3) he may charge himself with a trust or other equity in regard to the land. If, after diminishing his interest in either of the first two modes mentioned, he should make an ostensible conveyance of the whole land to an innocent purchaser, the latter would take only the diminished interest of his grantor; whereas if he should make a similar conveyance after reducing his interest in the third mode, the purchaser would take the legal title unincumbered. No reason occurs to the writer why a cestui que trust of land may not deal with his interest in the obligation of the trustee in a similar way, and with similar consequences. He certainly may transfer the whole or an aliquot part of the obligation, and he may grant a rent charge issuing out of it, and he may also charge himself as trustee, or subject himself to any other equity in regard to the obligation. It is also true that if the cestui que trust, after diminishing his interest by an assignment, should make an ostensible conveyance of his trust to an innocent purchaser, the latter would take subject to the previous assignment. Such a purchaser would also take subject to the annuity or rent charge. Finally, if the cestui que trust should convey his trust after charging himself with a subtrust, or other equity, the innocent purchaser ought to take the trust discharged from the sub-trust or other equity, as in the corresponding case the purchaser acquires an absolute title to the land. The analogy between the two cases would seem to be perfect."

What is said of land is not open to criticism. The owner of land may, without doubt, diminish his interest by a transfer of the whole or an aliquot part of the land. The transferee acquires the title to the whole or aliquot part as the case may be. Therefore the transferor has just so much less which he can subsequently transfer to another. But the transferee of the whole or an aliquot part of an equitable obligation or equitable chose in action acquires the title to nothing. "The assignee of an equitable chose in action, e.g., a trust," says Dean Ames, "of course sues in his own name without the aid of a statute. But here, too, there is no novation. If the Hibernicism may be pardoned, the assignee of a trust, like an attorney, stands in the place of his assignor, but he does not displace him. A release from the assignor to the innocent trustee frees the latter's legal title from the equitable incum- 
brance. Newman v. Nezeman, $28 \mathrm{Ch}$. Div., 674. So, if a cestui que trust should assign his trust first to $\mathrm{A}$, and then to $\mathrm{B}$, and $\mathrm{B}$ should, in good faith, obtain a conveyance of the legal title from the trustee, he could hold it as against A." ( 3 H. L. R., p. 342, note 1.)

The assignee of an equitable chose in action, therefore, like the assignee of a legal chose in action, acquires no title to the chose in action assigned. $\mathrm{He}$ is, therefore, not a true successor to the assignor. The assignment of an equitable chose in action, like the assignment of a legal chose in action, also works no novation. The obligation of the trustee to the assignor remains and is not extinguished and replaced by a new obligation of the trustee to the assignee. The assignor still retains the title to the equitable chose in action and that is why he can still release the trustee or make new assignments to new assignees.

What then is it that the assignee of an equitable chose in action gets? He gets, as does the assignee of a legal chose in action, a power of attorney from the assignor to reduce the equitable chose in action to a legal chose in possession and to retain it for his own benefit. If the assignee of a debt, a legal chose in action, in order to reduce it to possession, has to sue, he sues in a court of common law and in the assignor's name. If the assignee of an equitable chose in action has to sue the trustee to reduce it to a legal chose in possession, he sues in a court of equity and in his own name. These, however, are mere differences of detail in the exercise of the power of attorney. The important thing is that the equitable chose in action is extinguished and replaced by a legai chose in possession, the assignee's title to which is derived through the assignor.

There seems to be one important differenec between a legal and an equitable chose in action. If $\mathrm{A}$ owes $\mathrm{B} \$ 1,000$, the obligation of $A$ to $B$ is not divisible. $B$ can assign the whole of the chose in action to $\mathrm{C}$, even as a gift, and $\mathrm{C}$ gets a power of attorney to reduce the chose in action to a chose in possession and retain the chose in possession for his own benefit. But if $B$ assigns onehalf of the debt to $C$ and $C$ gives no value, he acquires no right. If however, $\mathrm{C}$ gives value for the assignment he gets an equitable lien or charge on the debt and may then sue in equity and reduce one-half of the legal chose in action to a legal chose in: possession and retain it for his own benefit. 
The abligation of a trustee to a cestui is in its nature, according to Dean Ames, divisible ( $1 \mathrm{H}$. L. R., p. 10 , note 2 ). As authority he cites Tierney v. Wood, 19 Beav., 330 (1854). Wood paid the purchase price for land and had the title conveyed to Tierney. A resulting trust thus arose. Wood wrote Tierney to hold the land after his death for the benefit of certain persons. Romilly, M. R., treated this writing as a declaration of trust by Wood and the case as raising the question whether Wood was the person, who, under the Statute of Frauds, was enabled to declare the trust. Wood, the cestui, had nothing of which he could declare himself a trustee except his equitable interest. He had no intention of making himself a trustee of that; but the writing operated as an assignment of his equitable interest to the persons named to take effect at his death. Ellison v. Ellison, 6 Ves. Jr., 656 (1802), decided by Lord Eldon seems to rest on the same principle.

In Smith and Snow v. Snow and Others, 3 Maddock, 10 (1818), the plaintiff, Smith, was assignee of Snow's one-seventh part in certain funds standing in the name of the defendant trustees. Smith and Snow sued the trustees and the other six cestuis to have Snow's one-seventh part transferred to Smith. The other cestuis demurred to the bill on the ground that they were improperly joined as parties and V. C. Leach sustained the demurrer. This appears to be a clear recognition of the divisibility of the trustee's equitable obligation.

Of course the cestui may create an equitable lien or charge on his equitable interest but not by an assignment of an aliquot part of his equitable interest. Thus if he directs the trustee to pay a given sum out of his equitable interest to a person other than himself and that person pays value, an equitable lien or charge is created. But if the person has given no value, he acquires no right. This last point was what was decided in In Re Lucan, L. R. 45 Ch. Div., 470 (1890).

The statement at p. 74 of the writer's Cases on Trusts that: "An assignment of a part of a cestui que trust's interest creates but an equitable charge, and is not valid without a consideration", is not a necessary conclusion from In Re Lucan $45 \mathrm{Ch}$. Div., 470 (1890), which is cited to support it and seems to be an error.

A cestui que trust of land may, without doubt, "transfer", as it is said, the whole or an aliquot part of his equitable interest. But such a "transfer", unlike the transfer made by the owner of land, does not diminish the transferor's interest. The owner of 
land, after transferring the whole, has none of his former title left; the owner of an equitable chose in action, after "transferring" the whole, has all of his former title left. Apart from recording acts, a second transferee from the owner of land never acquires anything. But Dean Ames says that "if a cestui que trust should assign his trust first to $A$, and then to $B$, and $B$ should, in good faich, obtain a conveyance of the legal title from the trustee, he could hold it against A". (3 H. L. R., p. 342, note 1 ). The position of the transferor of land, in whole or in part, and that of the "transferor" of an equitable chose in action, in whole or in part, are not analogous. So also the position of the transferee of land, in whole or in part, and that of the "transferee" of an equitable chose in action, in whole or in part, are not analogous.

It is true that, where the doctrine of Dearle $v$. Hall does not prevail, when there are successive transfers of the same equitable chose in action, just as when there are successive transfers of a legal chose in action, so long as no assignee has reduced the chose in action to possession and in good faith acquired the legal title to a chose in possession, equity says the first assignee has the right to the exclusion of the others to reduce the chose in action to a chose in possession and retain the same for his own benefit. That is all there is to Dean Ames' position "that if the cestui que trust, after diminishing his interest by an assignment, should make an ostensible conveyance of this trust to an innocent purchaser, the latter would take subject to the previous assignment." ( $1 \mathrm{H}$. L. R., pp. 10-11.) Yet if the latter, without notice of the previous assignment, reduces the equitable chose in action to a legal chose in possession he can hold it as against the first assignee. Is this taking his assignment subject to the previous one?

Dean Ames says that the owner of land may grant a rent charge issuing out of it, and that a subsequent purchaser for value, taking a conveyance without notice of the rent charge, takes subject to the rent charge. That is so; and it is because the rent charge is a right in rem, a real obligation, that is, an obligation that binds the land. He then says that a cestui que trust may grant a rent charge issuing out of his equitable interest and that, if the cestui que trust should afterwards make an ostensible conveyance of his trust to an innocent purchaser, the latter would take subject to the annuity or rent charge. In support of this proposition he relies on Phillips v. Phillips, 4 De G. F. \& J., 208 (1861), decided by Lord Chancellor Westbury. 
The assumption underlying this position is that the rent charge granted by the ceqtui to issue out of his equitable interest is like the rent charge granted by the owner of land to issue out of the land, that is, it is a right in rem, a real obligation binding not the cestui que trust personally, but the equitable personal obligation he has against the trustee.

A real obligation binding any chose in action, that is, a personal relation between a cestui que trust and his trustee, has never yet been recognized by equity and the idea finds no support in the decision in Phillips v. Phillips or in the opinion of Lord Westbury.

Equitable rights exist and are what they are because of the procedure prevailing in chancery. This Dean Ames has shown in his article "The Origin of Uses and Trusts" (21 H. L. R., pp. 261-274), in which he combats the view of Mr. Justice Holmes that the substantive law of equity is not merely the product of its procedure. Equity acts in personam and not in rem. It commands a person to do something or to refrain from doing something. Of necessity, therefore, every equitable right must be what Dean Langdell terms "an equitable personal obligation." (1 H. L. R., pp. 65-70.) Dean Ames himself so describes the right of the cestui que trust against his trustee $(1 \mathrm{H}$. L. R., pp. 9-10). Yet he would make an exception in the case of an annuity or rent charge granted by a cestui que trust. How he would describe the interest of the grantee of the rent charge we know not. It cannot be called an equity without confusion, for that term is confined to equitable personal obligations, and this is a real obligation. How could equity enforce a real obligation imposed upon a chose in action, not upon a corporeal thing?

In Phillips $v$. Phillips the person granting the annuity or rent charge was the owner of an equity of redemption. The grantee gave value. The grantor in anticipation of marriage then executed a deed of settlement. The plaintiff was the grantee of the annuity or rent charge and defendants were the children of the marriage and concededly purchasers for value of their equitable interest without notice of plaintiff's interest. But as their interest was an equitable interest, Lord Westbury held that the fact of purchase for value without notice was immaterial and their equitable interest was subject to the plaintiff's. He speaks of the plaintiff's interest as an annuity or rent charge, but his opinion shows that he did not regard his interest as like that of a grantee of a rent charge issuing out of land, namely, as a real rather than a personal 
obligation. He regarded the plaintiff's interest as an equity created by the owner of the equity of redemption and the defendant's interest as another equity created by the same person, but later than the plaintiff's, and that the plaintiff's equity was the better and superior simply because it was prior in time.

This is the view of the decision taken by Dean Langdell in his Equity Pleading (2nd ed.), sec. 191, p. 222.

The annuity or rent charge so-called granted to plaintiff in Phillips v. Phillips was nothing but an equitable lien or incumbrance on the grantor's equity of redemption and valid within the doctrine of In Re Lucan, 45 Ch. Div., 470 (1890), because the grantee paid value for it. That is, it was a right in personam, not a right in rem.

In discussing the nature of equitable rights, Dean Langdell says: 1 . "They must not violate the law. $* * * 4$. They must be such as can be enforced by the exercise of physical power in personam; for as equity has no other means of enforcing rights, it would be in vain for it to create what could not be so enforced. 5. Propositions one and four prove that no equitable right can be created, even by way of fiction, in analogy to either class of absolute rights, nor in analogy to real obligations."

We now pass to Dean Ames' last claim, namely, that, as the ownership of land held in trust may be transferred discharged of the trust to a purchaser for value without notice, so the ownership of the cestui's equitable interest held on a sub-trust may be transferred to a purchaser for value without notice discharged of the sub-trust.

The ownership of land, as we have seen, can be transferred. The ownership of the cestui's equitable personal obligation cannot be transferred. If $A$ holds the legal title to a physical res in trust for $B$, and $B$ declares himself a trustee of his equitable interest for $C$ and then assigns it to $D$, who takes the assignment and pays value without notice of C's equity, D gets no title, but a power of attorney to reduce B's equitable chose in action to a legal chose in possession and retain it for his own benefit. $D$, as attorney for $B$, can extinguish the equitable chose in action and receive from the trustee in lieu of it a legal chose in possession. It may be that the title to the legal chose in possession will pass directly from the trustee to $D, B$ 's attorney, instead of passing from the trustee first to $B$ and then from $B$ to $D$. But the legal consequences are the same as if the title passed from $A$ to $B$ and then from $B$ to $D$. 
If, therefore, $B$, when he gets title to the legal chose in possession, knows of the trust, he takes title by a new breach of trust and should hold his title subject to C's equity. It is unnecessary to repeat what has been said in the discussion of legal choses in action.

It will now be seen why it was necessary for Dean Ames to take the view he did of the decision in Phillips v. Phillips. Any other view would have been fatal to his last claim. Correctly understood the decision, we submit, is a powerful authority against Dean Ames' view, and a powerful authority in support of the view here put forward.

The owner of a chose in action, that is, of a personal obligation, legal or equitable, can by compelling the obligor to perform acquire title in the future to a legal chose in possession. When, instead of himself compelling performance, he assigns the personal obligation, he confers on the assignee a right as against himself to acquire title in the future to that chose in possession. The right so conferred is a right against the assignor personally and not against the future legal chose in possession, which at the time of the assignment may not even exist. When the obligation is performed and the legal chose in possession thereby comes into existence, the assignee's right to title thereto must be made effectual through his right against the assignor personally. This is clearly seen in the case of the assignee of a legal chose in action; for example, a debt, where the assignor refuses to permit the assignee to sue the debtor in a common law court in his name and he, therefore, sues in equity. He must make the assignor a party as he must work out his right to the legal chose in possession through his right against the assignor personally. So if the assignor of an equitable chose in action should dispute his assignment the assignee would have to join him in a suit in equity as well as the trustee, since here, too, he must work out his right to the legal chose in possession through his right against the assignor personally. The right, therefore, of an assignee of a personal obligation, legal or equitable, is as much an equity as the right of a vendee of land under a contract of purchase capable of specific performance against the vendor. That the first assignee's interest is destroyed when the second gets the legal title in good faith conclusively shows it to be an equitable interest.

If now the owner of a personal obligation, legal or equitable, assigns it first to $A$ and then to $B$, he creates the same equity 
in favor of each. As A's equity is the first created he should prevail over $B$, unless $B$ subsequently acquires the legal title and acquires it without notice of the assignment to $A$, that is, of $A$ 's equity. If we understand Dean Ames aright, he agrees with this position, for he says: "If a cestui que trust should assign his trust first to $A$, and then to $B$, and B should, in good faith, obtain a conveyance of the legal estate from the trustee, he could hold it against A." (3 H. L. R., p. 342, note 1.) If the words "in good faith" mean anything, they mean "without notice of the assignment to A", and the insertion of these words necessarily implies that if $B$ should get title from the trustee with notice of the assignment to A, he could not hold against A.

This concession seems fatal to both the first and third of Dean Ames' claims. If the second assignee, by obtaining in good faith a conveyance of the legal estate from the trustee, can destroy the first assignee's equitable interest, then his own assignment is not taken subject to the first assignment. If in order to destroy the first assignee's interest, the second assignee must acquire the legal estate "in good faith," that is, without notice of the first assignment, then the assignee for value and without notice of an equitable interest held subject to a sub-equity does not take free from the sub-equity.

We may sum up what we have said as follows: The assignee for value of a chose in action, legal or equitable, held in trust, must have no notice of the trust, not only when he takes the assignment and pays value, but also when he reduces the chose in action to a chose in possession and obtains title to the legal chose in possession. Otherwise he must hold the chose in possession subject to the trust. ${ }^{1}$

1 Dean Ames' view as to the position of a purchaser for value without notice of a cestui's interest held subject to a sub-trust was approved by Dean Langdell ( 1 H. L. R., p. 59, note 1 ). The writer, however, is informed that Dean Langdell subsequently withdrew this approval because he considered the view erroneous.

New York University.

Thaddeus D. Kenneson. 